ISSN: 1858-4837;E-ISSN: 2598-019X

Volume 16, Nomor 1 (2021),

https://jurnal.uns.ac.id/region

DOI: 10.20961/region.v16i1.37771

\title{
Model penataan lingkungan dengan melibatkan partisipasi masyarakat: Studi Kasus Kelurahan Banyuanyar Surakarta
}

\author{
Neighbourhood planning model involving community participation: Case Study \\ of Banyuanyar Village, Surakarta
}

\author{
Musyawaroh $^{1}$, L Pramesti ${ }^{1}$ \\ ${ }^{1}$ Study Program of Architecture, Faculty of Engineering, Universitas Sebelas Maret, \\ Surakarta, Indonesia
}

Corresponding author's email: musyawaroh@staff.uns.ac.id

\begin{abstract}
Abstrak. Konsep pembangunan dengan melibatkan partisipasi masyarakat sudah dilakukan di Indonesia sejak jaman dahulu, akan tetapi tidak dikembangkan dengan baik. Kendali pembangunan banyak berasal dari pemerintah secara top down dan tidak dapat dimanfaatkan dengan optimal. Penelitian ini bertujuan untuk merumuskan model rancangan lingkungan tertata selaras, sehat, produktif, berjatidiri dan berkelanjutan yang direncanakan dan dibangun dengan melibatkan partisipasi masyarakat. Metode penelitian yang digunakan adalah studi kasus dengan multi kasus, data diperoleh dari observasi lapangan, observasi partisipan, wawancara dan studi literatur, dokumen serta rekaman arsip. Penilaian keabsahan data melalui teknik derajat kepercayaan (credibility) dengan triangulasi, dan teknik pemeriksaan keteralihan (transferability) dengan cara uraian rinci. Proses analisis melalui: 1) penjodohan pola dan; 2) analisis antar objek. Penelitian ini menemukan konsep dan desain penataan lingkungan dengan melibatkan pertisipasi masyarakat yang disusun berdasarkan pemetaan potensi dan permasalahan di lapangan.
\end{abstract}

Kata Kunci: Model Perencanaan Lingkungan; Partisipasi Masyarakat

\begin{abstract}
The concept of development by involving community participation has been carried out in Indonesia since a long time ago but was not well developed. Much of the development control comes from the government top-down and cannot be utilized optimally. This research aims to arrange an environmental design model in harmony, healthy, productive, self-sustaining, and sustainable that is planned and built by involving community participation. The research method used is a case study with multiple cases, data obtained from field observations, participant observations,
\end{abstract}

Received : December 9, 2019; Accepted: August 8, 2020; Available online: January 30, 2021

Copy right @ 2021, REGION: Jurnal Pembangunan Wilay ah dan Perencanaan Partisipatif 
interviews and literature studies, documents, and archival records. Assessment of data validity was carried out through credibility techniques with triangulation and transferability examination techniques with a detailed description. The analysis process was done through: (1) pattern matchmaking; (2) analysis of trends; and (3) analysis between objects. This study found the concept and design of environmental management by involving community participation, which is based on the mapping of potential and problems in the study area.

Keywords: Community Participation; Neighborhood Planning Model

\section{Pendahuluan}

Penataan lingkungan membutuhkan peran serta semua pihak agar dapat berhasil dengan optimal, yaitu kerjasama antara pemerintah, masyarakat setempat, para ahli dan pemerhati lingkungan. Partisipasi masyarakat sangat dibutuhkan dalam perencanaan pembangunan, karena dapat memberikan solusi dalam menangani permasalahan serta merencanakan pembangunan yang tepat sasaran sesuai dengan kebutuhan masyarakat [1]. Pemberdayaan dan partisipasi sangat penting dilakukan dalam pembangunan, yang menjadi persyaratan dalam pelaksanaan hampir semua proyek dan program pemerintah [2]. Pemberdayaan masyarakat adalah suatu upaya untuk melatih kemampuan dan kemandirian masyarakat agar dapat berbuat sesuai dengan harkat dan martabat mereka dalam melaksanakan hakhak dan tanggung jawab mereka sebagai komunitas manusia dan warga negara [1, 2]. Dalam konsep pemberdayaan, masyarakat tidak dijadikan objek, tetapi menjadi subjek dari upaya pembangunannya sendiri.

Selanjutnya Hadi [2] menyebutkan bahwa partisipasi melibatkan dan mengikutsertakan masyarakat secara aktif dan sukarela, baik karena alasan-alasan dari dalam dirinya (intrinsik) maupun dari luar dirinya (ekstrinsik) dalam keseluruhan proses kegiatan. Lebih lanjut Abe dalam Hadi [2] mengemukakan bahwa melibatkan masyarakat secara langsung akan membawa dampak penting, yaitu: 1) terhindar dari peluang terjadinya manipulasi, karena memperjelas apa yang sebenarnya dikehendaki oleh masyarakat; 2) memberikan nilai tambah pada legitimasi rumusan perencanaan, semakin banyak masyarakat yang terlibat akan semakin baik; 3) meningkatkan kesadaran dan keterampilan politik masyarakat. Fadil [1] mengemukakan bahwa agar bisa bermanfaat, pembangunan seharusnya menerapkan prinsip-prinsip desentralisasi, bergerak dari bawah (bottom up), mengikutsertakan masyarakat secara aktif (participatory), dilaksanakan dari dan bersama masyarakat (from and with people). Akan tetapi pada saat ini banyak kegiatan pembangunan yang tidak dilaksanakan dengan melibatkan aspirasi masyarakat, sehingga tidak dapat memenuhi kebutuhan masyarakat dengan baik.

Kota Surakarta atau lebih dikenal dengan Solo sebagai kota budaya, dengan luas sekitar 44,04 km² yang terdiri dari 5 Kecamatan (Banjarsari, Jebres, Laweyan, Pasar Kliwon, Serengan) dan 51 Kelurahan, dengan jumlah penduduk 545.653 jiwa berdasarkan Dinas Kependudukan dan Pencatatan Sipil Kota Surakarta dalam Diskominfo SP Kota Surakarta [3]. Kecamatan yang paling luas adalah Banjarsari 14,81 km2, terdiri dari 13 kelurahan dengan 
jumlah penduduk 157.438 jiwa. Sebagai salah satu kota besar, Pemerintah Kota Solo berkeinginan untuk menjadikan Solo sebagai kota yang berkelanjutan sesuai dengan SDGs poin ke-11 kota dan komunitas yang berkelanjutan yaitu kota yang memungkinkan orang untuk maju secara sosial dan ekonomi. Tantangan yang ada saat ini adalah mempertahankan kota dengan terus menciptakan lapangan kerja dan kemakmuran tanpa menyita tanah dan sumber daya, kemacetan, kurangnya dana untuk menyediakan layanan dasar, kekurangan perumahan yang memadai dan infrastruktur yang menurun [4].

Salah satu upaya yang telah dilakukan oleh Pemerintah Kota Solo adalah mencanangkan Solo Eco-Cultural City 2015, yang penataan lingkungannya telah dilakukan tahun 2012 dan 2015 bekerjasama dengan Prodi Arsitektur dan Prodi PWK Fakultas Teknik UNS. Dari 28 kelurahan yang didampingi oleh UNS, 22 berhasil menyusun konsep penataan lingkungan dan 20 di antaranya mengikuti lomba yang dilaksanakan. Upaya ini telah membuahkan hasil, tapi belum semua kelurahan (lingkungan) mau terlibat. Perlu dilakukan evaluasi dan pengembangan agar semua masyarakat mau terlibat dan lebih bermanfaat maksimal bagi masyarakat serta lingkungan.

\section{Metode}

Jenis penelitian adalah applied research [5], memberikan jawaban praktis atas masalah nyata secara langsung dan spesifik tentang penurunan kualitas lingkungan yang perlu ditangani dengan segera. Pendekatan yang digunakan yaitu kualitatif rasionalistik.

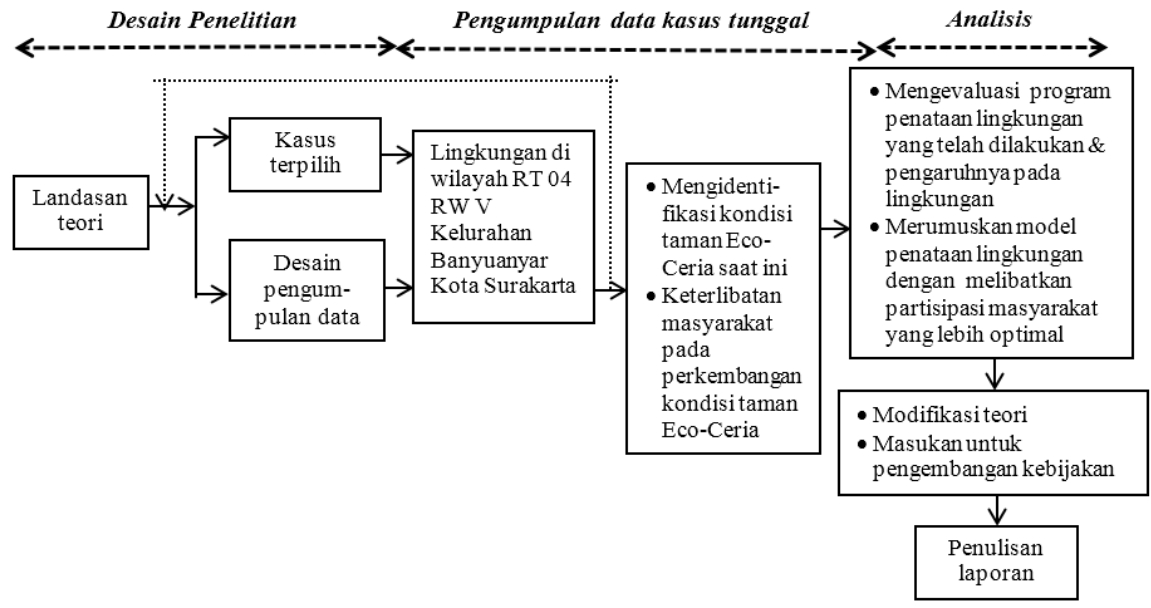

Gambar 1. Metode penelitian kualitatif studi kasus tunggal [6].

Metode yang digunakan adalah studi kasus, dengan kasus tunggal [6], yaitu area Taman EcoCeria di RT 04 RW V Kelurahan Banyuanyar. Sumber dan jenis data terdiri dari : 1) Data primer (foto, gambar, kondisi lingkungan saat ini, dan wawancara dengan masyarakat yang terlibat kegiatan di Taman Eco-Ceria terdiri dari pamong praja, RT, RW, PKK dan tokoh masyarakat terkait); 2) Data sekunder berupa sumber tertulis dari makalah, artikel, jurnal, prosiding, dokumen undang-undang/peraturan/kebijakan pemerintah dan buku terkait [7]. Data yang diperoleh dianalisis secara diskriptif kualitatif berdasarkan teori partisipasi 
masyarakat dan penataan lingkungan, kemudian dikembangkan berdasarkan temuan lapangan untuk menemukan konsep dan model penataan lingkungan yang lebih tepat (Gambar 1).

\section{Hasil dan pembahasan}

Model penataan lingkungan di Kelurahan Banyuanyar melibatkan partisipasi masyarakat secara aktif, hal ini sangat dibutuhkan agar dapat memberikan solusi untuk menangani permasalahan serta merencanakan pembangunan yang tepat sasaran sesuai kebutuhan. Penataan lingkungan membutuhkan peran serta semua pihak agar dapat berhasil dengan optimal, sesuai teori Fadil [1]. Fokus utama rancangan lingkungan adalah pada penguatan dan pengembangan sosial kapital melalui pengokohan nilai-nilai universal dan kearifan lokal (perilaku), lingkungan dan sosial (community services), serta dengan membuka ruang kreativitas dan inovasi untuk menciptakan sumberdaya pembangunan permukiman mereka (community entrepreneurship) sesuai teori Budiyanto [8].

\subsection{Program penataan lingkungan di Kelurahan Banyuanyar}

Pada tahun 2012 Dinas Tata Ruang Kota Surakarta mengadakan Lomba Rancang Tata Ruang Lingkungan dengan melibatkan pendampingan dari Prodi Arsitektur dan PWK FT UNS, yang diikuti oleh semua kelurahan di Kota Surakarta. Maksud diad akannya lomba ini yaitu:

1) Mengajak masyarakat untuk mengekspresikan gagasan/ide dalam bentuk rancang tata ruang kawasan strategis lingkungannya.

2) Mendorong masyarakat untuk lebih peka terhadap potensi dan permasalahan lingkungan serta ikut berpartisipasi dalam merancang ruang kota.

3) Mewujudkan rancang tata ruang lingungan kota sesuai kebutuhan masyarakat.

Stakeholders yang terlibat adalah :

1) Pemerintah kota Surakarta sebagai penyelenggara.

2) Dosen Arsitektur dan PWK UNS sebagai pengarah tehnis kegiatan.

3) Mahasiswa Arsitektur dan PWK UNS sebagai pendamping teknis peserta.

4) Konsultan PNPM sebagai tim teknis pendamping.

5) Solo Kota Kita sebagai tim teknis pendamping.

Sejumlah dosen dari Prodi Arsitektur dan Prodi PWK Fakultas Teknik Universitas Sebelas Maret telah melakukan pendampingan terhadap 28 kelurahan di Kota Surakarta. Dari 28 kelurahan yang didampingi oleh UNS, 22 berhasil menyusun konsep penataan lingkungan dan 20 di antaranya mengikuti lomba Tata Ruang Lingkungan Kota (TRLK) yang dilaksanakan oleh Dinas Tata Ruang Kota Surakarta. Dari 22 konsep dan desain penataan tersebut, menjadikan DTRK Surakarta juara 1 dalam lomba tata ruang tingkat nasional.

Dari pendampingan pada beberapa kelurahan, salah satu kelurahan telah mengembangkan dan membangun rancangan lingkungan yang telah disusun adalah Kelurahan Banyunyar. Contoh taman lingkungan yang telah ditangani dan berhasil dikembangkan serta dibangun (pada tahun 2012) adalah open space RT 04 RW V Banyuanyar yang terletak di lahan bekas kuburan. Awalnya, pada area tersebut telah dibangun Posyandu-PAUD dan pos Iansia, akan tetapi lingkungan sama sekali belum tertata dengan baik. 
Langkah-langkah pendampingan yang telah dilakukan oleh peneliti dan tim adalah sebagai berikut:

1) Sosialisasi pendampingan lomba TRLK.

2) Penjajakan kebutuhan/usulan lokasi dari masyarakat (dari musrenbangkel, PNPM dII.).

3) Pembentukan kelompok kerja (kelurahan).

4) Kriteria/penentuan lokasi.

a) Terdapat aspek eco-cultural di wilayah tersebut

b) Memiliki permasalahan lingkungan yang mendesak untuk ditangani

c) Dapat dikembangkan

d) Program dapat terus berkelanjutan

5) Survey lapangan :

a) Kondisi eksisting lingkungan

b) Data potensi kawasan

c) Mempunyai jejaring dengan lingkungan dan Kota

d) Kondisi sosial, ekonomi \& budaya masyarakat setempat

e) Kedepannya memiliki prospek yang bagus

6) Identifikasi permasalahan yang ada

7) Pengolahan data

8) Pembuatan desain penataan

9) Koordinasi dan sosialisasi dengan masyarakat

10) Menyempurnakan hasil rancangan

11) Pencetakan desain rancangan penataan

12) Mengajukan dalam lomba TRLK

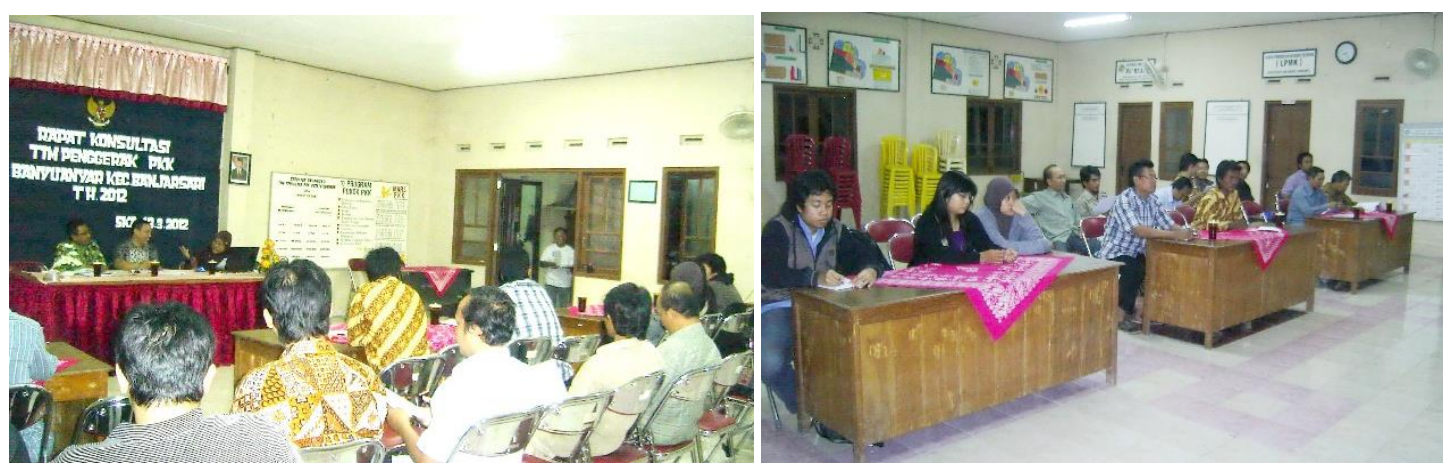

Gambar 2. Sosialisasi kegiatan dengan masyarakat Banyuanyar [9].

Pada tahap awal, dilakukan sosialisasi program pendampingan penataan lingkungan dalam rangka ikut lomba TRLK. Sosialisai dilakukan terhadap Pamong Praja dan tokoh masyarakat yang terkait (pengurus PKK, karangtaruna, RT-RW, PNPM dan lain-lain). Dari sosialisasi tersebut dipetakan potensi permasalahan lingkungan yang ada, berdasarkan masukan dari masyarakat setempat (Gambar 2).

Lokasi kawasan yang akan ditangani ditentukan berdasarkan hasil identifikasi potensi dan permasalahan yang dikemukakan oleh masing-masing RW, kemudian diberikan skoring 
terhadap indikator yang telah ditetapkan. Hasil terhadap identifikasi potensi dan permasalahan dapat dilihat pada Tabel 1.

Tabel 1. Identifikasi potensi dan masalah [9].

\begin{tabular}{|c|c|c|c|c|c|c|c|c|}
\hline \multirow[t]{2}{*}{ No. } & \multirow[t]{2}{*}{ Wil. } & \multirow[t]{2}{*}{ Potensi } & \multirow[t]{2}{*}{ Permasalahan } & \multicolumn{4}{|c|}{ Kriteria } & \multirow[t]{2}{*}{ Jml. } \\
\hline & & & & 1 & 2 & 3 & 4 & \\
\hline 1. & RW V & $\begin{array}{l}\text { 1. Posyandu \& Pos PAUD } \\
\text { telah terba ngun dan rutin } \\
\text { digunakan } \\
\text { 2. Posyandu telah meraih } \\
\text { kejuaraan tingkat Jateng } \\
\text { \& Nasional } \\
\text { 3. Eksisting lahan siap guna } \\
\text { 4. Terdapat kesenian Reog, } \\
\text { Keroncong \& Band } \\
\text { 5. Tersedia buku untuk } \\
\text { taman baca } \\
\text { 6. KegiatanTPAibu-ibu } \\
\text { 7. Masyarakat mendukung } \\
\text { penuh }\end{array}$ & $\begin{array}{l}\text { 1. Posyandu \& Pos PAUD } \\
\text { belum memiliki tempat } \\
\text { bermain } \\
\text { 2. Belum tersedia: } \\
\text { - Tempat bermain anak di } \\
\text { wil. RW V \& RW IV } \\
\text { - Tempat berkes enian } \\
\text { untuk warga } \\
\text { - Taman baca } \\
\text { 3. Wilayah sekitar lahan } \\
\text { menja di permukiman } \\
\text { kumuh/illegal }\end{array}$ & 6 & 6 & 6 & 6 & 24 \\
\hline 2. & RW VI & $\begin{array}{l}\text { Gedung untuk Posyandu } \\
\text { Lansia \& Balita Telah tersedia } \\
\text { seluas } 6 \times 10 \text { m2 }\end{array}$ & $\begin{array}{l}\text { 1. Membutuhkan jaringan } \\
\text { listrik \& sumur/air bersih } \\
\text { 2. Dukungan masyarakat } \\
\text { kurang }\end{array}$ & 2 & 4 & 2 & 4 & 12 \\
\hline 3. & RW VII & $\begin{array}{l}\text { 1. Terdapat kes enian, } \\
\text { karawitan, ketoprak, } \\
\text { keroncong \& campur sari } \\
\text { 2. Mempunyai lahan tanah } \\
\text { Negara, di tepi Kali Pepe }\end{array}$ & $\begin{array}{l}\text { 1. Merupakan lahan } \\
\text { penggaliantanah } \\
\text { 2. Belumada talud } \\
\text { 3. Dukungan masyarakat } \\
\text { kurang }\end{array}$ & 6 & 6 & 4 & 4 & 20 \\
\hline 4. & RW VIII & $\begin{array}{l}\text { 1. Mempunyai lahan unit } \\
\text { pengolahan sampah } \\
\text { bimbingan dari Solo } \\
\text { Technopark (dikelola KTI) } \\
\text { 2. Kegiatanpelatihan } \\
\text { pewarnaan batikalami } \\
\text { 3. Mempunyai lahan tanah } \\
\text { negara, di tepi Kali Pepe }\end{array}$ & $\begin{array}{l}\text { 1. Menjadi TPS sampah } \\
\text { 2. Pengelolaantidak } \\
\text { transparan } \\
\text { 3. Dukungan masyarakat } \\
\text { kurang }\end{array}$ & 6 & 4 & 6 & 4 & 20 \\
\hline 5. & RW X & $\begin{array}{l}\text { 1. Mempunyai lahan tanah } \\
\text { negara, di tepi Kali Pepe } \\
\text { 2. Pemanfaatan lahan } \\
\text { sebagai kios sepeda \& } \\
\text { counter pulsa }\end{array}$ & $\begin{array}{l}\text { 1. Lahan digunakan untuk } \\
\text { TPS terbuka kumuh \& } \\
\text { kotor } \\
\text { 2. Berupa Iahan bekas } \\
\text { kuburan } \\
\text { 3. Dukungan masyarakat } \\
\text { kurang }\end{array}$ & 6 & 6 & 6 & 4 & 22 \\
\hline & & $\begin{aligned}: 1 & =\text { Terdapat aspek eco-cu } \\
2 & =\text { Memiliki permasalaha } \\
3 & =\text { Dapat di kembangkan } \\
4 & =\text { Program dapat terus be } \\
\cdot 6 & =\text { baik } \cdot 4=\text { cukun } \cdot 2=\text { kur }\end{aligned}$ & $\begin{array}{l}\text { ral di wilayah tersebut } \\
\text { lingkungan yang mendesak } \\
\text { lanjutan }\end{array}$ & & & & & \\
\hline
\end{tabular}


Dari hasil penilaian yang telah dilakukan dengan dipandu oleh pendamping, ditentukan dua area yang menjadi prioritas yaitu open space (bekas kuburan di RW V) dan area sekitarTPS di RW X.
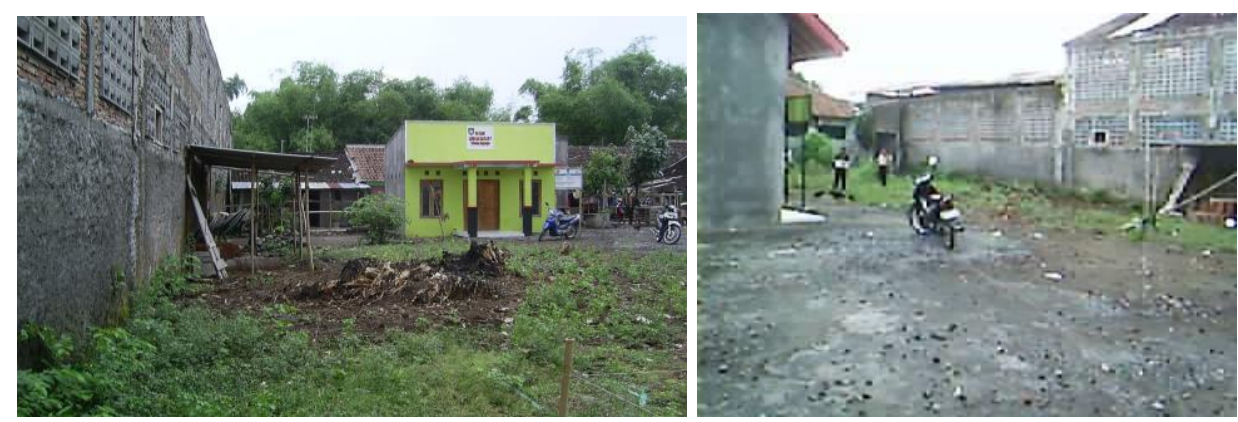

Gambar 3. Kondisi awal area RW V objek penelitian [9].

Pada area open space di RW V yang akan dirancang telah dibangun Posyandu-Pos PAUD dan Posyandu Lansia, akan tetapi kondisi lingkungan belum tertata dengan baik (Gambar 3). Sedangkan pada area TPS RW X kondisinya belum siap bangun dan sangat kumuh.

Setelah menentukan lahan yang akan mendapatkan prioritas penanganan, selanjutnya dibentuk kelompok kerja pelaksanaan. Kelompok kerja bertanggungjawab terhadap pelaksanaan kegiatan, dengan susunan organisasi terdiri dari seluruh lapisan masyarakat. Pokja diketuai oleh tokoh masyarakat yang berkompeten dalam pelaksanaan kegiatan.

\subsection{Penataan Taman Eco-Ceria RT 04 RW V Banyuanyar}

Untuk menangani penataan Taman Eco-Ceria di Kelurahan Banyuanyar, Musyawaroh dkk. [9] merancang usulan sebagai berikut.

\section{a. Latar belakang}

Solo merupakan kota yang sedang berkembang menjadi kota besar, kegiatan perekonomian meningkat, investasi semakin kondusif yang berdampak banyak didirikan bangunan komersial seperti mall, hotel, ruko atau rukan dan juga perumahan. Pembangunan yang pesat ini berdampak terhadap hilangnya area hijau/lahan terbuka di perkotaan, dan menyebabkan semakin minimnya ruang untuk tempat rekreasi dan tempat bermain anak.

Anak-anak di wilayah perkotaan cenderung bermain di jalan, bantaran sungai, beralih ke mall atau bahkan gadget. Kota modern tidak ramah untuk anak, dapat menyebabkan semakin renggangnya hubungan sosial antar warga dan menimbulkan pengelompokanpengelompokan peruangan yang terpisah dalam area perkotaan.

Sebagai Kota Layak Anak, Solo harus mampu mengakomodasi berbagai kebutuhan anak agar dapat hidup, tumbuh dan berkembang dengan layak sebagai bagian dari kehidupan masyarakat. Oleh karena itu diberikan usulan program Taman Eco Ceria yang berlokasi pada RT 04 RW V Kelurahan Banyuanyar Kecamatan Banjarsari. Konsep penataan ruang yang ekologis diperlukan, untuk menjaga kelestarian lingkungan. 
Dengan program tersebut, aktivitas masyarakat dapat terwadahi dengan baik. Khususnya penyediaan ruang tempat bermain anak dan tempat berkegiatan budaya masyarakat, menyediakan open space yang aktif untuk mendukung pengembangan Solo sebagai kota layak anak dan Eco-Cultural City.

\section{b. Potensi dan masalah}

Permasalahan yang ada di RT 04 RW V yaitu masih banyak penduduk di wilayah ini adalah golongan Pra Sejahtera yang mencapai $>40 \%$. Bagi mereka rumah hanya digunakan sebagai tempat berlindung dari panas dan hujan, minim fasilitas penunjang kegiatan keluarga. Dampak tidak adanya wadah fasilitas bermain, anak-anak bermain di sepanjang gang dalam kampung. Selain itu wilayah ini sering mendapatkan bantuan dana dari PNPM maupun block grant, karena banyaknya jumlah keluarga yang kurang mampu. Wilayah ini perlu ditata untuk meningkatkan kualitas hidup masyarakatnya.

Adapun potensi yang dimiliki RW $V$ yaitu :

a) Penduduk usia balita (0-5 th) berjumlah 164 anak, paling banyak di Kelurahan Banyuanyar.

b) Memiliki tanah negara siap bangun (bekas kuburan), dengan bangunan Posyandu dan Pos PAUD di dalamnya.

c) Posyandu dan Pos PAUD telah aktif digunakan.

Jadwal kegiatan tetap Posyandu balita di wilayah ini adalah sebulan sekali hari Selasa minggu pertama, sedangkan Posyandu lansia diadakan hari Jumat minggu ke empat. Posyandu balita ini pernah menjadi juara I tingkat propinsi dan juara II tingkat nasional tahun 2008. Sebagai penghargaan atas prestasi tersebut, Pemkot membangunkan Pos PAUD yang saat ini ada. PKK Kelurahan Banyuanyar menjadi pembina Pos PAUD tersebut, dan jumlah siswanya mencapai 30 anak dari RW IV, V, IX, dan Sawahan, Boyolali. Disamping itu, di tempat ini juga menjadi rintisan "rumah baca" melalui kegiatan pengumpulan buku oleh warga setempat.

Pada wilayah RW V juga terdapat potensi budaya berupa kesenian reog, keroncong, dan band yang aktif. Latihan keroncong dilakukan setiap malam Jumat dan latihan band pada setiap Minggu siang di rumah Bapak Imam RT 3 RW V. Latihan reog diadakan saat akan ada acara untuk tampil, perlengkapan reog disimpan di rumah Bapak Subur pada RT 2 RW V.

Untuk semua potensi tersebut diperlukan fasilitas yang dapat mewadahinya, oleh karena itu disusun program perancangan "Taman Eco Ceria" pada lahan yang telah tersedia di RT 4 RW V. Dengan penataan Taman Eco-Ceria, diharapkan menumbuhkan motivasi warga sehingga pada periode berikutnya dapat dilakukan penataan pada permukiman kumuh yang ada di sekitar lokasi dengan dana PNPM, Block Grant, CSR atau Swadaya masyarakat.

Kesimpulan yang dapat diambil dari uraian di atas yaitu :

a) Open space di wilayah RT 4 RW V ditata sehingga dapat mewadahi sebagai tempat bermain anak dan berkesenian warga.

b) Perlu dilakukan perbaikan lingkungan berupa penghijauan, pembuatan biopori, sumur resapan, jaringan drainase, sanitasi dan penataan permukiman kumuh. 
c. Dasar konsep penataan

Program "Taman Eco Ceria" (Gambar 4) mencakup dua unsur, kata "eco" mewakili penataan lingkungan yang ekologis dan kata "ceria" yang mewakili penyediaan tempat bermain untuk anak.

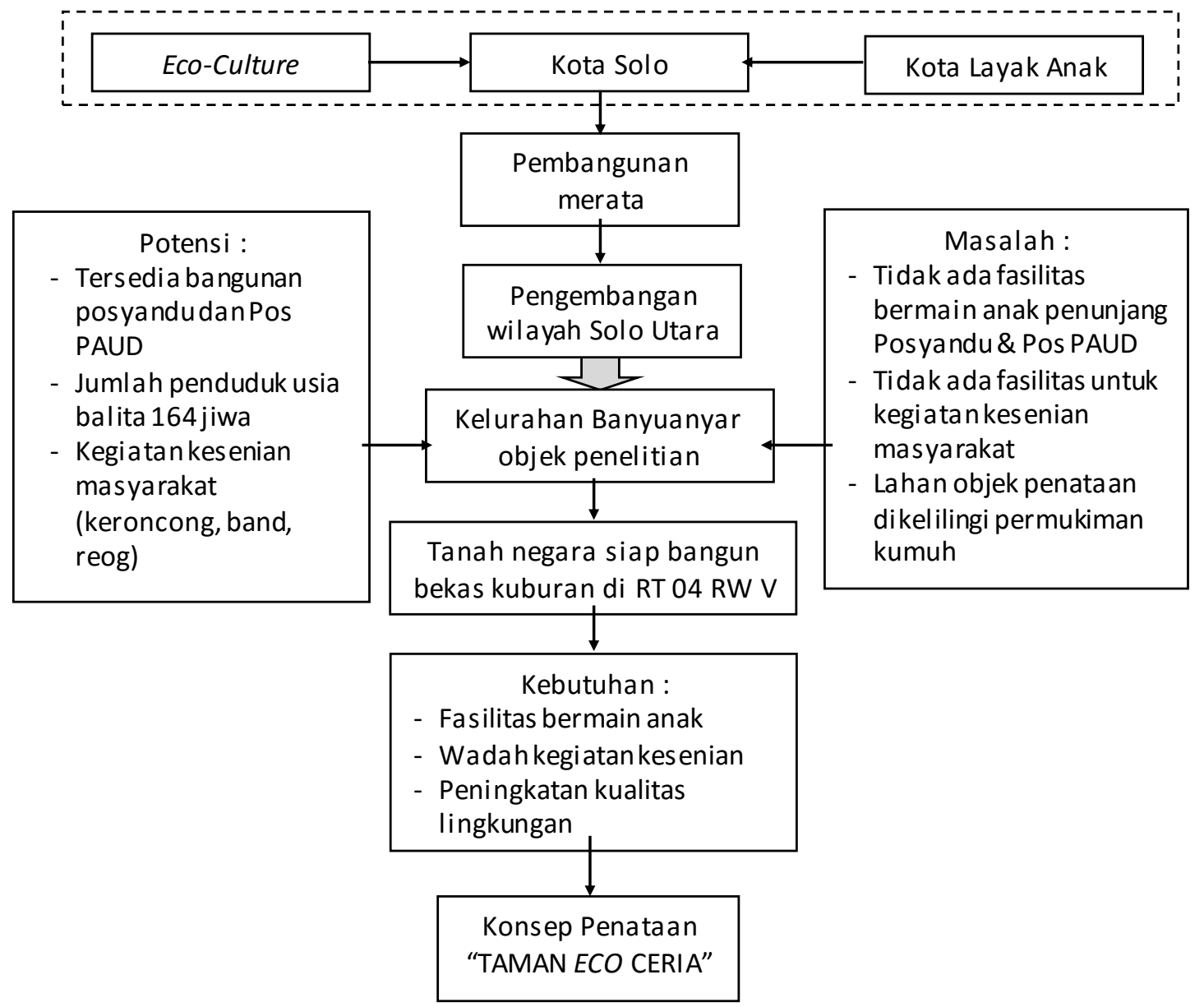

Gambar 4. Skema konsep usulan program [9].

Konsep ekologis pada Taman Eco-Ceria diterapkan dengan: 1) penghijauan dengan penanaman pohon, pembuatan biopori, pembuatan sumur resapan, penggunaan grass block untuk perkerasan serta penyempurnaan saluran drainase dan sanitasi.

Dengan pembuatan biopori, sumur resapan dan pemasangan grass block, air hujan dapat lebih maksimal masuk ke dalam tanah untuk mendukung upaya konservasi air. Jenis biopori yang diterapkan di area ini yaitu : 1) biopori murni yang berisi sampah organik dilapisi tanah dengan kedalaman $1 \mathrm{~m}$ dan diameter $20 \mathrm{~cm}$, untuk area yang tidak tertutup grass block dibuat; 2) biopori yang berisi sampah dedaunan dengan kedalaman $1 \mathrm{~m}$ dan diameter $20 \mathrm{~cm}$, untuk area yang tertutup grass block.

Sumur resapan di area taman yang terbuat dari pasangan batu bata tanpa plester, digunakan untuk menampung saluran drainase dari rumah kumuh yang berada di sekitar lahan. Pada tepi sungai dibuat sumur pengolahan, untuk menampung limbah air cucian baju maupun 
piring. Limbah ini disalurkan dari masing-masing ke sumur pengolahan, baru dibuang ke badan air (sungai) agar tidak mencemari lingkungan. Berikut model desain Taman Eco-Ceria (lihat Gambar 5).
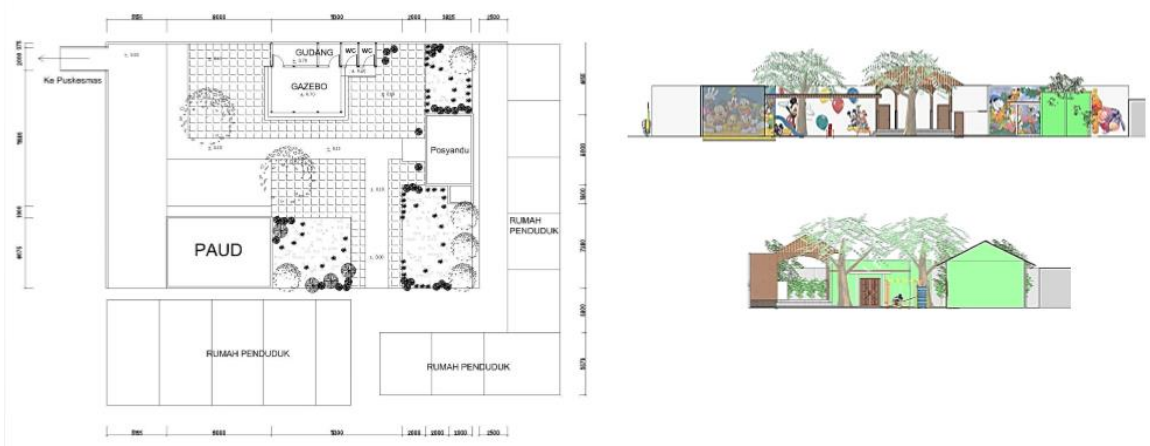

Gambar 5. Model desain Taman Eco-Ceria [9].

Seperti telah dikemukakan sebelumnya, fasilitas yang disediakan pada "Taman Eco-Ceria" mewadahi kegiatan bermain anak dan kegiatan kesenian waraga. Fasilitas bermain anak diletakkan di depan Pos PAUD dan Posyandu agar anak-anak mudah mengakses area ini, selain itu diberikan akses agar anak-anak dari wilayah RT 04 RW V bisa ikut memanfaatkan area bermain tersebut pada sore/siang hari (saat Posyandu dan POS PAUD sudah tutup).

Akses bagi Posyandu Lansia, disediakan akses masuk prasarana jalan dengan perkerasan beton untuk mencegah agar Lansia tidak tersandung/jatuh. Untuk aktivitas kesenian, disediakan gazebo untuk tempat latihan, bangunan ini juga dapat digunakan untuk ruang baca bagi anak-anak, pertemuan warga dan acara warga lainnya). Sebagai kelengkapan dari gazebo, disediakan gudang dan kamar mandi untuk kenyamanan kegiatan. Untuk menjaga kebersihan lingkungan, disediakan bak sampah organik \& anorganik.

\subsection{Evaluasi pada pelaksanaan program yang telah dilakukan}

Setelah usulan program diajukan pada lomba TRLK tahun 2012, maka proses pendampingan secara resmi dihentikan. Akan tetapi Pokja yang dibentuk (walaupun tidak menang dan tidak mendapatkan bantuan dana), dengan motivasi penuh meneruskan dan melaksanakan kegiatan yang direncanakan. Dengan berbekal proposal dan gambar desain yang telah dimiliki mereka berusaha menggandeng semua pihak untuk mendapatkan bantuan untuk merealisasikannya.

Upaya memberdayakan masyarakat agar bisa berpartisipasi aktif di Kelurahan Banyuanyar dapat dikatakan telah berhasil. Hal ini sesuai dengan pendapat Sumodiningrat [11] bahwa pemberdayaan masyarakat dengan mendorong, memotivasi dan membangkitkan kesadaran atas potensi yang dimilikinya serta berusaha untuk mengembangkannya telah memandirikan masyarakat lewat perwujudan potensi kemampuan yang mereka miliki.

Tokoh masyarakat merupakan stakeholder terkait dengan penyediaan dan penataan RTH, pada kondisi di lapangan tokoh masyarakat yang selalu terlibat yaitu Lembaga Pemberdayaan Masyarakat Kelurahan (LPMK) yang berperan sebagai wakil dari masyarakat 
yang memberikan usul kepada Lurah dan pihak lain dalam kegiatan pembangunan dan kemasyarakatan [10]. Di Kelurahan Banyuanyar, semua tokoh masyarakat setempat ikut berpartisipasi dalam penataan Taman Eco-Ceria terdiri dari RT, RW, Karangtaruna dan tokoh lainnya. Untuk merealisasikan rancangan yang telah dibuat, Pokja telah berhasil memperoleh bantuan dari :

1) Dana Block Grant pada akhir tahun 2012, sebesar 20 juta, yang digunakan untuk membangun gazebo dan gudang.

2) TNI Manunggal Membangun Desa pada tahun 2013, pavingisasi lahan.

3) Pihak Swasta, membangun pagar di bagian utara taman.

Pada tahun 2015 DTRK merencanakan akan memberikan bantuan dana untuk menyempurnakan pembangunan Taman Eco-Ceria, tim pendamping (dari Arsitektur UNS) bersama Pokja telah menyusun kembali serta menyempurnakan hasil rancangan dengan lebih detail akan tetapi program tersebut tidak jadi dilaksanakan.

Secara fisik belum bangunan Taman Eco-Ceria ini belum ideal, disebabkan tidak ada pendampingan teknis saat proses pembangunan sehingga tidak ada yang mengontrol kesesuaian pelaksanaan dengan gambar rancangan yang telah dibuat. Ketidaksesuaian tersebut adalah pada hal sebagai berikut.

1) Seluruh lahan taman dipenuhi dengan paving block tanpa penghijauan sama sekali, hal ini menjadikan taman semakin panas dan gersang sehingga kurang nyaman digunakan sebagai area bermain anak (Gambar 6). Menurut desain yang diusulkan, pada sebagian area dipasang grass block dan sebagian yang lain dibiarkan terbuka untuk penghijauan.

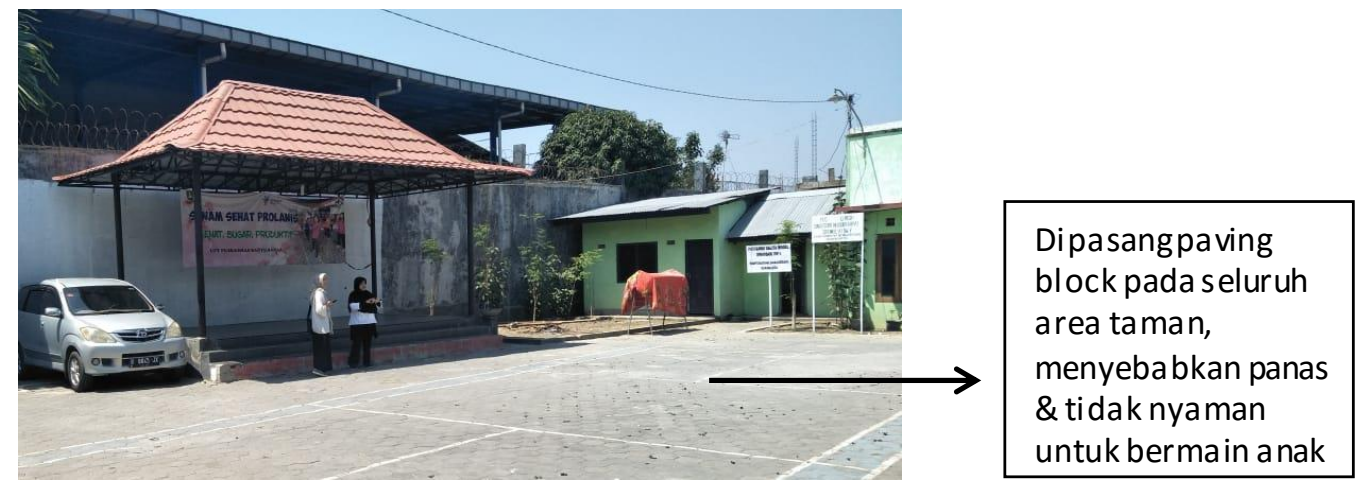

Gambar 6. Kekurangan pada realisasi program.

2) Tidak terdapat tanaman penghijauan pada area taman, sehingga area ini menjadi sangat panas di siang hari.

3) Area ini belum dilengkapi dengan biopori dan sumur resapan.

Meskipun demikian, Pokja dan masyarakat di RT 04 RW V dan RW X telah berhasil membangun/menata lingkungannya berkat kegigihannya dalam meraih partner kerjasama dengan semua pihak. Hal ini patut dijadikan contoh bagi kawasan lainnya. 


\subsection{Model penataan lingkungan dengan melibatkan partisipasi masyarakat}

Dalam proses penataan Taman Eco-Ceria, tim pendamping selalu melibatkan partisipasi masyarakat setempat (Pokja). Masyarakat secara aktif dan sukarela ikut terlibat dalam keseluruhan proses kegiatan, hal ini sesuai dengan pendapat Hadi. Dengan melibatkan partisipasi masyarakat maka: 1) akan memperjelas apa yang dibutuhkan oleh masyarakat; 2) memberikan nilai tambah pada legitimasi rumusan perencanaan; 3) meningkatkan kesadaran dan keterampilan masyarakat dalam membela kepentingan lingkungannya [2].

Penataan Taman Eco-Ceria diawali dari informasi masyarakat tentang lingkungan yang bermasalah dan potensi yang dimiliki pada wilayahnya, yang membutuhkan prioritas untuk segera ditangani (bottom up) pada tim pendamping. Dalam membuat rancangan penanganannya, masyarakat diikutsertakan secara aktif (participatory). Kemudian program yang telah disusun tersebut dilaksanakan bersama masyarakat (from and with people) hal ini sesuai dengan teori Fadil [1]. Pemberdayaan masyarakat mengikuti pendekatan sebagai berikut: 1) terarah, ditujukan langsung kepada yang memerlukan dengan program yang dirancang untuk mengatasi masalahnya dan sesuai kebutuhannya; 2) langsung mengikutsertakan atau bahkan dilaksanakan oleh masyarakat yang menjadi sasaran; 3) menggunakan pendekatan kelompok, karena paling efektif dan lebih efisien [11].

Tipe partisipasi masyarakat Banyuanyar dalam penataan lingkungan adalah partisipasi interaktif yaitu masyarakat memiliki peran untuk mengontrol keputusan-keputusan mereka, dan memiliki andil dalam keseluruhan proses kegiatan sesuai teori Pretty dalam Usmaniya [12]. Bentuk partisipasi mereka adalah kombinasi antara collaboration dan co-learning, masyarakat Banyuanyar dan pihak Arsitektur UNS saling membagi pengetahuannya, untuk memperoleh saling pengertian, dan bekerjasama untuk merencanakan aksi. Selanjutnya pihak Arsitektur UNS membuatkan proposal dan gambar rancangan, sedangkan untuk proses realisasinya diserahkan kepada masyarakat setempat. Keterlibatan partisipasi masyarakat dalam penataan taman eco-ceria yakni:

1) Mengikuti acara sosialisasi kegiatan yang dilakukan oleh tim pendamping.

2) Memberikan informasi kepada tim pendamping tentang potensi dan permasalahan lingkungan yang ada di wilayahnya.

3) Ikut menentukan pemeringkatan prioritas permasalahan lingkungan yang harus segera ditangani.

4) Membentuk Pokja yang akan melaksanakan kegiatan penataan di wilayahnya.

5) Bersama tim pendamping merancang skedul pelaksanaan.

6) Mendampingi tim pendamping saat survey lapangan.

7) Memberikan informasi kegiatan yang dilakukan dan kebutuhan masyarakat, sebagai dasar perancangan fasilitas yang akan dibangun.

8) Memberikan masukan/saran pada pra-desain rancangan.

9) Menyetujui/menyepakati hasil rancangan yang telah dibuat tim pendamping.

10) Mengusulkan kegiatan yang dilaksanakan pada lomba TRLK 2012.

11) Merealisasikan kegiatan. 
Pada saat dilaksanakan program pendampingan, tim pendamping menjalin kerjasama yang baik dengan Pokja yang telah dibentuk dan berusaha memotivasi/membangkitkan kesadaran masyarakat akan potensi yang telah dimilikinya agar bisa membangun fasilitas yang direncanakan secara mandiri (bukan tergantung pada subsidi dana yang hanya diberikan pada pemenang lomba TRLK). Hal ini dilakukan untuk mengantisipasi macetnya kegiatan kalau tidak memenangkan perlombaan. Proposal dan gambar desain yang telah dibuat bisa dipakai untuk mengajukan bantuan pendanaan kepada dinas/pihak lain yang bersedia membantu.

Pada tahun 2015, Dinas Tata Ruang Kota Surakarta memprogramkan akan memberi subsidi dana untuk penyempurnaan Taman Eco-ceria yang sudah mulai terbangun. Tim pendamping dari Arsitektur UNS bersama Pokja menyempurnakan kembali desain yang telah dibuat, masyarakat terlibat aktif dalam penyempurnaan gambar dan perubahan rencana anggaran biaya yang diusulkan. Sangat disayangkan program ini tidak jadi terlaksana.

Setelah dibangun gudang, gazebo, MCK dan pavingisasi di area Taman Eco-ceria, maka taman ini bisa mewadahi tidak hanya Posyandu Balita dan Posyandu Lansia saja, akan tetapi ditambah lagi dengan kegiatan sosial kemasyarakatan sebagai berikut (Tabel 2).

Tabel 2. Jenis kegiatan yang diwadahi oleh Taman Eco-Ceria [13].

\begin{tabular}{llll}
\hline No & \multicolumn{1}{c}{ Kegiatan } & \multicolumn{1}{c}{ Waktu } & \multicolumn{1}{c}{ Pelaku } \\
\hline 1 & Arena bermain & Setiap sore hari & Anak-anak \\
2 & Bulutangkis & Insidental & Remaja \& Anak-anak \\
3 & Dasawisma & Rutin setiap bulan & Ibu-Ibu PKK \\
4 & Halal bi halal & Rutin setelah lebaran & Warga RT.04/RT.05 \\
5 & Kampung belajar (wajib belajar) & Setiap hari, pukul: 18.30-20.00 & Anak-anak \\
6 & PAUD & Senin-Jumat, pukul:08.00-10.00 & Anak-anak \& guru \\
7 & Posyandu Balita & Minggu II/bulan & Balita \\
8 & Posyandu Lansia & Minggu III/bulan & Lansia \\
9 & Resepsi pernikahan & Insidentil & Warga dan kerabat \\
10 & Senam & Setiap Jumat pagi & Lansia \& muda \\
11 & Silat & (sudah berhenti) & \\
12 & Tasyakuran 17-an & Setiap tanggal 17 Agustus & Warga RT.04/RW.05 \\
13 & Tempat TPS (Pemilu) & Insidentil & Remaja-Dewasa \\
14 & Tempat menyimpanbaranginventaris RW & Tetap & Pengurus RW \\
\hline
\end{tabular}

Dampak positif lainnya pasca dibangunnya Taman Eco-Ceria adalah, rumah illegal yang ada di sekitar taman telah mendapatkan sertifikat Prona pada tahun 2018 dari Pemerintah Pusat. Setelah taman dapat dimanfaatkan dengan lebih baik, pihak Puskemas membangun rumah dinas karyawan di bagian Barat area ini.

Kondisi saat ini Taman Eco-Ceria dapat dilihat pada Gambar 7 dimana taman ini dikelola oleh pengurus RT dan RW secara Community Based Management yaitu perencanaan, pelaksanaan serta pengelolaan hasil-hasil pembangunannya yang dipelihara/dikelola oleh masyarakat setempat, dengan prinsip "Good" sesuai teori Budiyanto [8]. Untuk lebih melengkapi kegiatan di dalamnya, Pamong Praja Banyuanyar berharap untuk selanjutnya 
taman ini bisa dikembangkan menjadi taman baca. Hal ini bisa terlaksana dengan perencanaan sharing tempat dan waktu yang lebih baik.

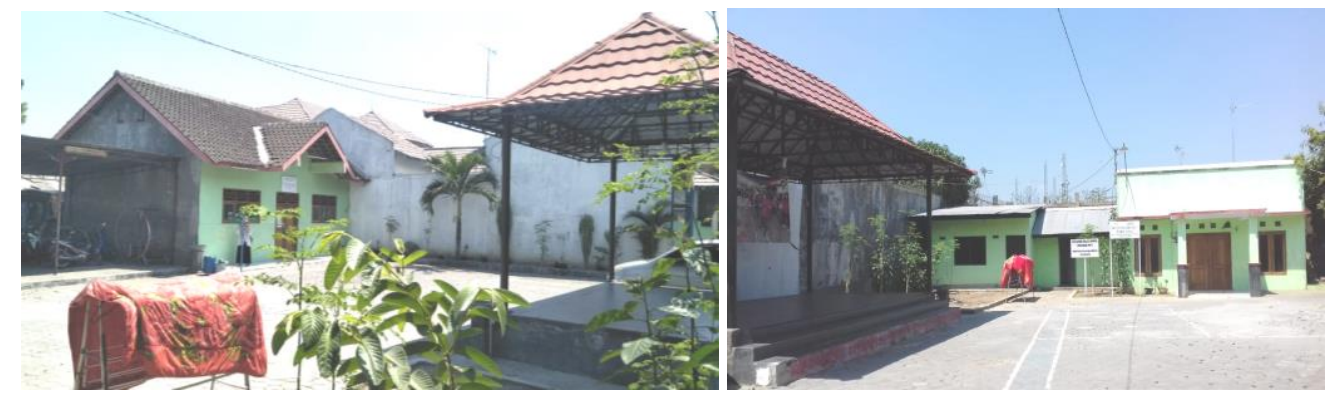

Gambar 7. Kondisi Taman Eco-Ceria saat ini.

Model penataan lingkungan dengan melibatkan partisipasi masyarakat yang diterapkan untuk Kelurahan Banyuanyar sesuai dengan teori Musyawaroh dkk. [13], lihat Gambar 8.

Segitiga model penataan lingkungan partisipatif mencakup tiga hal utama yaitu lingkungan dengan potensi dan permasalahannya, pemerintah/swasta sebagai penyedia dana serta partner/pendamping sebagai motivator, fasilitator tim teknis pembuat usulan dan desain rancangan. Ke tiga hal tersebut didukung oleh partisipasi masyarakat sebagai motor penggerak, dengan partisipasi aktif masyarakat penataan lingkungan bisa berjalan dengan baik dan tepat sasaran sehingga dapat dimanfaatkan secara optimal.

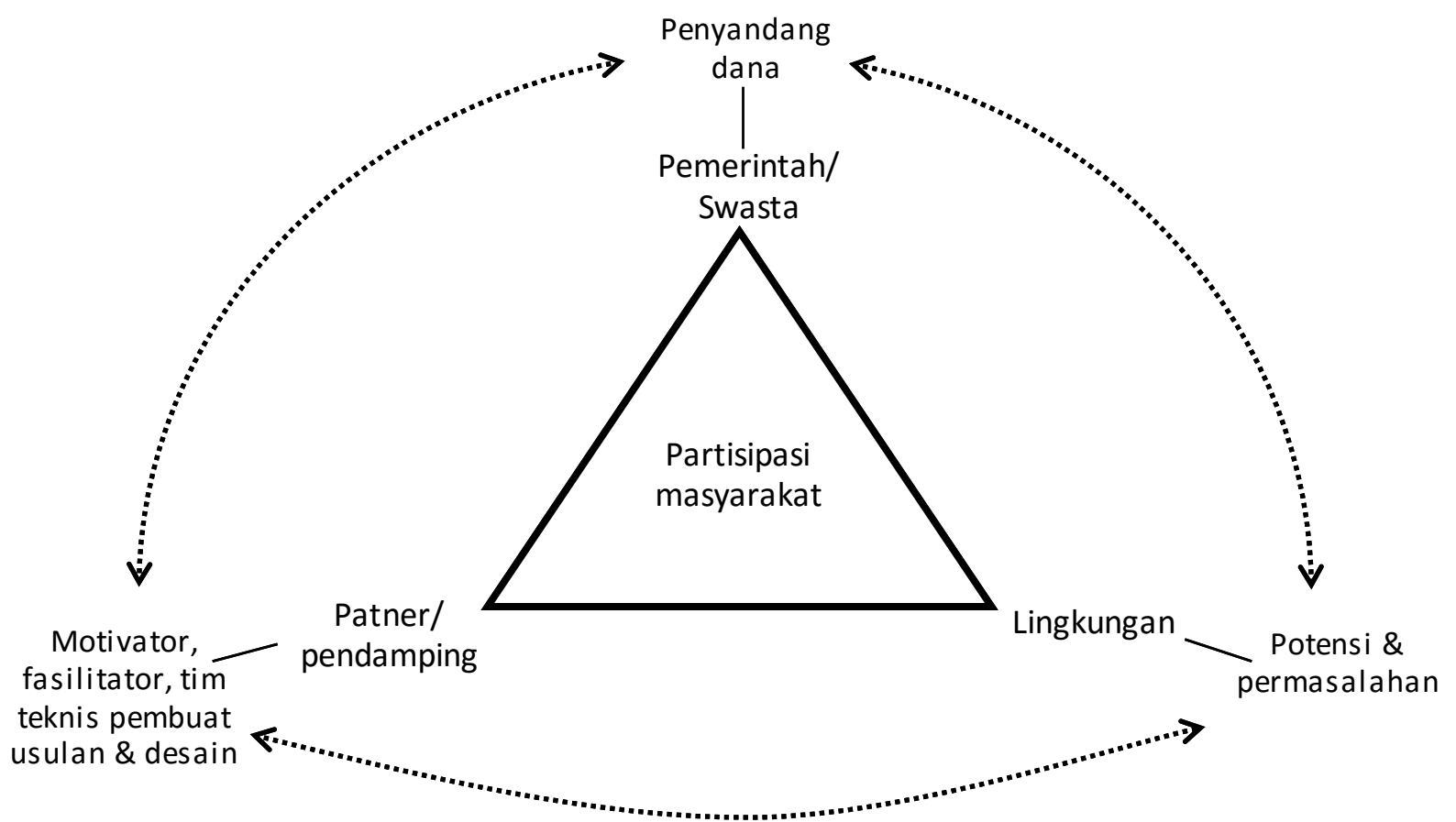

Gambar 8. Model penataan lingkungan partisipatif

\section{Kesimpulan}

Program pendampingan penataan lingkungan di RT 04 RW V Kelurahan Banyuanyar Surakarta telah dilakukan oleh peneliti dan tim pada tahun 2012 dalam rangka membantu 
program (lomba TRLK) yang dicanangkan Dinas Tata Kota Surakarta. Tim pendamping membuat proposal dan rancangan desain Taman Eco-Ceria, berdasarkan pemetaan potensi permasalahan yang disusun bersama masyarakat. Untuk mendukung kegiatan tersebut pihak kelurahan membentuk Pokja, yang terdiri dari tokoh masyarakat setempat.

Kelurahan Banyuanyar bukan menjadi pemenang dalam lomba tersebut, akan tetapi masyarakat dapat merealisasikan Taman Eco-Ceria yang telah direncanakan dengan menggandeng pihak lain sebagai penyandang dana. Realisasi program kurang sesuai dengan usulan rancangan, karena tidak ada pendampingan teknis (kegiatan pendampingan tidak berlanjut).

Model penataan lingkungan untuk RT 04 RW V Kelurahan Banyuanyar adalah "segitiga model penataan lingkungan partisipatif" yang mencakup tiga hal utama yaitu lingkungan, pemerintah/swasta serta partner/pendamping. Partisipasi masyarakat sebagai motor penggerak, tidak akan bisa berhasil dengan baik tanpa dukungan dari semua pihak.

\section{Ucapan Terima Kasih}

Terima kasih yang sebesar-besarnya kami ucapkan kepada :

1) Pamong Praja Kelurahan Banyuanyar.

2) Tokoh Masyarakat RT 04 RW V Kelurahan Banyuanyar.

Yang telah memberikan data dan informasi bagi penelitian ini.

Tak lupa kami ucapkan terima kasih kepada :

1) Program Studi of Arsitektur Fakultas Teknik Universitas Sebelas Maret yang telah memberikan kesempatan dan ijinnya untuk melakukan penelitian.

2) Kepada semua pihak yang telah membantu, yang tidak bisa kami sebutkan satu-persatu.

\section{Referensi}

[1] Fadil F 2013 Partisipasi Masyarakat dalam Musyawarah Perencanaan Pembangunan di Kelurahan Kotabaru Tengah Jurnal IImu Politik dan Pemerintahan Lokal 22 pp 25162 Diakses dari https://ppjp.ulm.ac.id/journal/index.php/JIPPL/article/view/897

[2] Hadi A P 2010 Konsep Pemberdayaan, Partisipasi Dan Kelembagaan Dalam Pembangunan Yayasan Agribisnis/Pusat Pengembangan Masyarakat Agrikarya (PPMA) Diakses dari http://suniscome.50webs.com/32\%20Konsep\%20Pemberdayaan\%20Partisipasi\%20 Kelembagaan.pdf

[3] Dinas Komunikasi Informatika Statistik dan Persandian Kota Surakarta 2018 Indikator Ekonomi Kota Surakarta Tahun 2017 Diakses dari https://diskominfosp.surakarta.go.id/wp-content/uploads/2019/11/Buku-IndikatorEkonomi-Kota-Surakarta-Tahun-2017.pdf

[4] Kementerian PPN/Bappenas 2017 Pedoman Penyusunan Rencana Aksi Tujuan Pembangunan Berkelanjutan (TPB)/Sustainable Development Goals (SDGs) Diakses dari http://sdgs.bappenas.go.id/wpcontent/uploads/2017/09/Buku_Pedoman_RAN_TPB.pdf 
[5] Neuman W L 2013 Metodologi Penelitian Sosial : Pendekatan Kualitatif Dan Kuantitatif Ed. 7 (Jakarta: PT. Indeks)

[6] Yin R K 2013 Studi Kasus : Desain dan Metode (Jakarta: Raja Grafindo Persada)

[7] Moleong L 2004 Metodologi Penelitian Kualitatif (Bandung: PT. Remaja Rosdakarya)

[8] Budiyanto H 2011 Pendampingan Dalam Proses Perencanaan Partisipatif Program Penataan Lingkungan Permukiman Berbasis Komunitas (PLPBK) Jurnal $\begin{array}{llllrll}\text { Local Wisdom } & 3 & 1 & \mathrm{pp} & 34-40 & \text { Diakses dari }\end{array}$ http://jurnal.unmer.ac.id/index.php/lw/article/view/1386

[9] Musyawaroh dkk 2012 Taman Eco - Ceria RT 04 RW V Kelurahan Banyuanyar [Tidak Dipublikasikan] Materi Lomba TRLK 2012 (Surakarta: Tim Pendamping Prodi Arsitektur Fakultas Teknik UNS)

[10] Prabowoningsih N H, Putri R A, dan Rini E F 2018 Faktor- Faktor Yang Mempengaruhi Ketersediaan Ruang Terbuka Hijau Pada Setiap Dominasi Penggunaan Lahan, Studi Kasus: Kota Surakarta Jurnal Region 132 pp 133-151 DOI: 10.20961/region.v13i2.21158

[11] Sumodiningrat G 1999 Jaring Pengaman Sosial Dan Pemberdayaan Masyarakat Jurnal Ekonomi dan Bisnis Indonesia $14 \quad 3 \quad$ Diakses dari https://jurnal.ugm.ac.id/jieb/article/view/39431

[12] Usmaniya D 2014 Partisipasi Masyarakat Dalam Penyelenggaraan Program Pelaksanaan Kelompok Usaha Bersama (Kube) di Kelurahan Dompak Kecamatan Bukit Bestari Kota Tanjungpinang Tahun 2013 Skripsi (Tanjungpinang: universitas Maritim Raja Ali Haji) Diakses dari http://jurnal.umrah.ac.id/wpcontent/uploads/gravity_forms/1ec61c9cb232a03a96d0947c6478e525e/2015/06/JURNAL1.pdf

[13] Musyawaroh, Suroto W, Pramesti L dan Mustaqiemah U 2019 Model Penataan Lingkungan Melibatkan Partisipasi Masyarakat Berbasis Pembangunan Berkelanjutan di Surakarta (Surakarta: LPPM Universitas Sebelas Maret) 